\title{
Laboratory study of the effect of saturation degree on quality of fair-faced concrete surfaces
}

Kitti AJTAYNÉ KÁROLYFI

is assistant lecturer and PhD student at the Department of Structural and Geotechnical Engineering, Széchenyi István University. Area of scientific interest: concrete technology, fairfaced concrete, digital image processing.

Ferenc PAPP

KıтTI AJTAYNÉ KÁROLYFI - Department of Structural and Geotechnical Engineering, Széchenyi István University, Hungary - karolyfi.kitti@sze.hu

FERENC PAPP - Department of Structural and Geotechnical Engineering, Széchenyi István University, Hungary · pappfe@sze.hu

Érkezett: 2021. 03. 26. - Received: 26. 03. 2021. - https://doi.org/10.14382/epitoanyag-jsbcm.2021.17

\begin{abstract}
The concrete composition is one of the most significant factor influencing the quality of the fairfaced concrete surfaces. Practical experiences showed, that in case of architectural concrete slightly oversaturated concrete mixtures result in higher quality surfaces. In this work the surface quality of fair-faced concrete samples was examined depending on the saturation degree of the cement paste and the dimensions of the mould. The main evaluation aspects were the surface void ratio, the discoloration, the honeycomb and bleeding. The surface void ratio was obtained by using digital image processing techniques, while the other surface irregularities were examined using manual methods. The concrete samples were classified according to the Austrian and German guidelines. The effect of saturation degree on the mechanical properties of the concrete was also studied. Results show that the increase in saturation degree of cement paste improves significantly the surface quality, while the dimensions of the mould have a reduced, but also a positive effect. In the meantime, there is a decrease in the mechanical properties of the concrete. Keywords: fair-faced concrete, surface quality, saturation degree, surface void ratio

Kulcsszavak: látszóbeton, péptelítettség, felületi minôség, felületi pórustartalom
\end{abstract}

\section{Introduction}

Fair-faced concrete surfaces have become even more popular in today's architecture due it's advantageous mechanical properties and high surface quality [1]. The final appearance of the surface is strongly influenced by the used concrete composition. Practical experiences show, that the saturation degree of the cement paste is a key factor in improving the surface quality. Regarding the saturation degree three conditions of the fresh concrete can be identified: the mixture is undersaturated if there is less cement paste than the void content of the aggregate (Fig. 1 a); the mixture become saturated if the cement paste fills the gaps between the particles (Fig. 1 b); if there is more cement paste than the void content the particles are distancing from each other and the mixture becomes oversaturated (Fig. $1 \mathrm{c}$ ). In the case of fair-faced concrete surfaces a slightly oversaturated condition is recommended according to the practical experience [2]. However, it can be assumed, that the ideal saturation degree of cement paste depends on the dimensions of the structural element and the required surface quality.

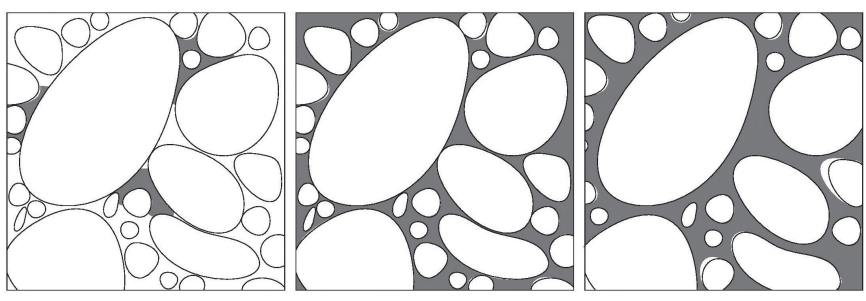

Fig. 1 a) Undersaturated, b) saturated and c) oversaturated conditions of concrete mix

1. ábra a) Telítetlen, b) telített és c) túltelített betonkeverék
The saturation degree affects on the mechanical properties of hardened concrete as well. In principle, the void content of saturated or oversaturated mixtures is zero, while the undersatured mixtured have air content in some degree, therefore the hardened concrete will have lower compressive strength. However, if the water-cement ratio is greater than 0.38 , the porosity of the oversaturated mixture is increasing which results in decrease in the compressive strength as well $[3,4]$.

\section{Materials and methods}

During the experiments a total number of 12 fair-faced castin-place concrete wall samples were made by using 3 moulds of different sizes (Fig. 2) and 4 types of concrete mixtures. Furthermore, 6 cube and 3 beam specimens were also casted from each concrete compositions in order to examine the mechanical properties of the hardened concrete.

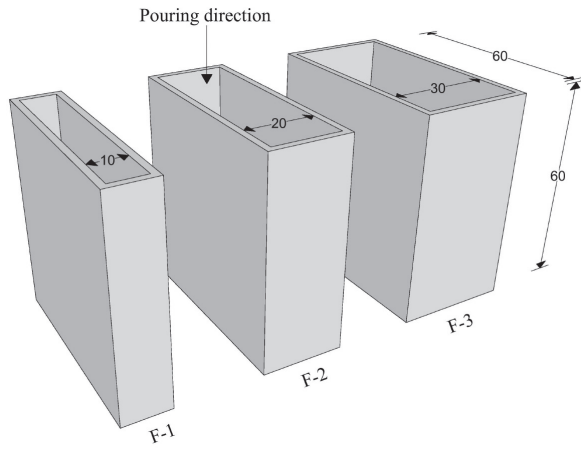

Fig. 2 Dimensions and marking of the moulds

3. ábra Az alkalmazott zsaluzatok mérete és jelölése 


\subsection{Materials}

Quartz sand and gravel was applied as aggregate originated from a quarry pond in Hungary. The rounded fine and coarse fractions were divided with sieving method into components of the following sizes: $0.063,0.125,0.25,0.5,1,2,4,8,16,32$ $\mathrm{mm}$. The components were mixed according to the particle size distribution of the standard limit curve 'C' [5]. The relative density and the bulk density of the aggregate sample was measured and the packing density was calculated, from which the precise value of the cement paste demand could be defined [6].

The facing material was 3-ply formwork sheet with $120 \mathrm{~g} / \mathrm{m}^{2}$ phenolic resin coating on both sides. Mineral oil based, mould release agent was applied in order to prevent adherence between the concrete and the mould and provide a smooth concrete surface.

Four concrete compositions were mixed with increasing amount of cement and water beside a constant water-cement ratio of 0.50 (Table 1). CEM II/A-S portland slag cement was used for the mixes. Superplasticizer was applied in order to assure similar characteristics of fresh concrete by reaching the F4 consistency class according to the flow table test [7]. The moulds were filled with fresh concrete in 3 layers by using internal vibration. Each samples were kept in moulds for 3 days.

\begin{tabular}{|c|c|c|c|c|}
\hline No. & $\begin{array}{l}\text { Cement } \\
{\left[\mathrm{kg} / \mathrm{m}^{3}\right]}\end{array}$ & $\begin{array}{l}\text { Water } \\
{\left[\mathrm{l} / \mathrm{m}^{3}\right]}\end{array}$ & $\begin{array}{c}\text { Aggregate } \\
{\left[\mathrm{kg} / \mathrm{m}^{3}\right]}\end{array}$ & $\begin{array}{c}\text { Saturation degree } \\
\qquad\left[\mathrm{l} / \mathrm{m}^{3}\right]\end{array}$ \\
\hline 1. & 330 & 165 & 1893.38 & +76.45 \\
\hline 2. & 360 & 180 & 1828.35 & +101.13 \\
\hline 3. & 390 & 195 & 1763.33 & +125.81 \\
\hline 4. & 420 & 210 & 1698.30 & +150.48 \\
\hline
\end{tabular}

Table 1. Concrete compositions

1. táblázat Alkalmazott betonösszetételek

\subsection{Evaluation methods}

The evaluation of the surface quality is a complex problem due to the versatility of fair-faced concrete and the lack of regulation in several countries. In Hungary, the MSZ EN 24803 [8] standard can be used for assessment, which deals with the requirements for the appearance of building structural elements, not expressly the fair-faced concrete. In Austria, the ÖNORM B2211 [9] standard and the fair-faced concrete guideline [10] is the basis of evaluation, while in Germany only the guideline [11] can be used. These specifications usually define four concrete classes with tolerances for the different evaluation criteria. These aspects are examined manually, therefore some criteria, such as discoloration can be evaluated only subjectively. A few research was intended to develop automatic evaluation methods by using digital image processing techniques and reported promising results $[12,13]$.

In this study the surface quality of the samples was examined on two sides with the dimensions of $60 \times 60 \mathrm{~cm}$. The main evaluation aspects were the surface void ratio, the discoloration, the honeycomb and bleeding. In the case of the surface void ratio a newly developed method was applied for the evaluation based on digital image processing techniques. The algorithm was created by using Python software, which method requires one photo of the examined surface. The basis of the method is fitting a third order polynomial to the previously created image containing the selected regions which are free from surface defects. The detection of surface void ratio is made based on the difference between the original and the fitted image using contour finding methods. The algorithm was tested on reference surfaces and it was concluded that it overestimates the results of the manual method with a maximal of $5 \%$, however the time needed for the process is a fraction of it [14]. The mechanical properties of the hardened concrete were examined by measuring the compressive strength, the flexural strength and the water penetration at 28 days.

\section{Results}

\subsection{Surface quality}

\subsubsection{Surface void ratio}

The surface void ratio was evaluated on reference surfaces with a size of $50 \times 50 \mathrm{~cm}$ cutted out from the photo of each samples. Three intervals of the pores' diameter were examined: a. between 0.01 and $15 \mathrm{~mm}$;

b. between 1 and $15 \mathrm{~mm}$ according to the Hungarian standard and Austrian guideline;

c. between 2 and $15 \mathrm{~mm}$ according to the German guideline.

The surface void ratio decreases significantly while the saturation degree and the width of the formwork increases. Results show a considerable difference between the values of the three diameter intervals (Fig. 3). In the case of the 4. mixture the surface void ratio decreases by $20-48 \%$ if the minimal pore diameter was changed from 0.01 to $1 \mathrm{~mm}$ due to the large number of smaller pores of these surfaces. In general, these values halve by increasing the minimal diameter from 1 to $2 \mathrm{~mm}$.

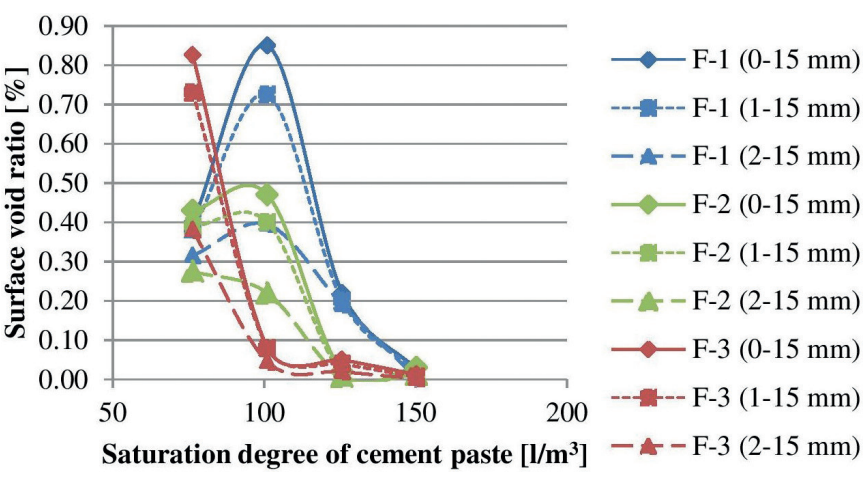

Fig. 3 Surface void ratio of the samples according to the three diameter intervals 3. ábra Felületi pórustartalom a vizsgált pórusátmérö-intervallumok szerint

The results of the examination can be seen in Table 2 in detail by using the diameter interval between 0.01 and $15 \mathrm{~mm}$. The increase in saturation degree results in a decrease of the average quantity of the pores by $91.8 \%$, the expected value of the diameter by $29.5 \%$, the variance by $77 \%$, the standard deviation by $53 \%$ and the surface void ratio by $96.4 \%$. The increase in the width of the mould has a reduced effect on surface quality with a decrease in the pore quantity by $21 \%$ and the surface void ratio by $35.1 \%$. The distribution of the pores was also examined by their diameter with a precision of $0.5 \mathrm{~mm}$. The skewness and the kurtosis of the distribution is positive in all cases, which 
means that the pores with smaller diameter $(\mathrm{d} \leq 2 \mathrm{~mm})$ are in greater proportion and the distribution has a peak around these values. Furthermore, the increase in saturation degree results in a growth of the skewness by $27.7 \%$ and the kurtosis by $68.1 \%$, while there is no significant change in these values with increasing width of the mould.

\begin{tabular}{|c|c|c|c|c|c|c|c|c|}
\hline \multirow{2}{*}{ Aspect } & & \multicolumn{4}{|c|}{ Concrete composition } & \multicolumn{3}{|c|}{ Mould } \\
\hline & & 1. & 2. & 3. & 4. & 1. & 2. & 3. \\
\hline $\begin{array}{l}\text { Average quan- } \\
\text { tity of pores }\end{array}$ & {$[p c]$} & 680 & 696 & 107 & 56 & 453 & 343 & 358 \\
\hline $\begin{array}{l}\text { Average ex- } \\
\text { pected value }\end{array}$ & {$[\mathrm{mm}]$} & 1.76 & 1.52 & 1.37 & 1.24 & 1.50 & 1.43 & 1.48 \\
\hline $\begin{array}{l}\text { Average value } \\
\text { of variance }\end{array}$ & {$[\mathrm{mm}]$} & 1.87 & 0.99 & 1.41 & 0.43 & 1.74 & 0.98 & 0.80 \\
\hline $\begin{array}{l}\text { Average of } \\
\text { standard } \\
\text { deviation }\end{array}$ & {$[\mathrm{mm}]$} & 1.32 & 0.98 & 1.10 & 0.62 & 1.21 & 0.95 & 0.86 \\
\hline $\begin{array}{l}\text { Average of } \\
\text { surface void } \\
\text { ratio }\end{array}$ & [\%] & 0.55 & 0.47 & 0.10 & 0.02 & 0.37 & 0.24 & 0.24 \\
\hline $\begin{array}{l}\text { Skewness of } \\
\text { the distribution }\end{array}$ & {$[-]$} & 2.78 & 2.99 & 3.49 & 3.55 & 3.32 & 2.98 & 3.32 \\
\hline $\begin{array}{l}\text { Kurtosis of the } \\
\text { distribution }\end{array}$ & {$[-]$} & 7.56 & 8.36 & 11.98 & 12.71 & 11.01 & 8.35 & 11.10 \\
\hline
\end{tabular}

Table 2. Main results of the surface void examination (diameter interval: 0.01-15 mm) 2. táblázat A felületi pórustartalom vizsgálat föbb eredményei (pórusátmérö-intervallum: 0,01-15 $\mathrm{mm}$ )

\subsubsection{Discoloration}

The increase in saturation degree of the cement paste improves significantly the quality of the surfaces under in regard to the discoloration constant mould dimension, and vice versa (Fig. 4). The samples made of the 4 . concrete composition reached the highest quality class according to the German and Austrian guideline. The Hungarian standard uses a previously accepted reference surface to evaluate the colour tone of the examined element, therefore this is not relevant here.

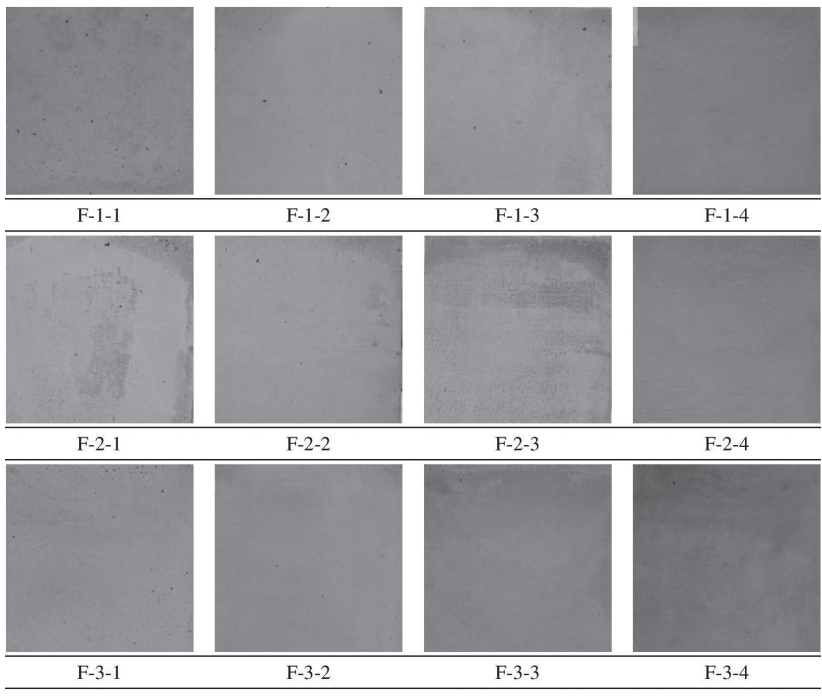

Fig. 4 Surfaces of the samples ordered by the applied mould (F-1-F4) and concrete composition (1-4)

4. ábra A próbatestek felületei az alkalmazott zsaluzat (F-1-F-4) és betonösszetétel (1-4) szerint

\subsubsection{Honeycomb and bleeding}

Different levels of honeycomb and bleeding occurred on the samples near to the edges. These irregularities can be avoided by the use of proper sealing in the joints of the sheets. The affected area is decreasing with increasing saturation degree of the cement paste and the best result was shown on the samples made by the F-3 mould (Fig. 5)

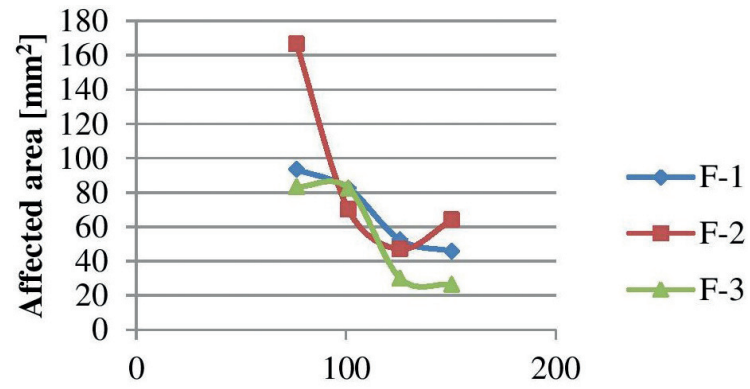

\section{Saturation degree of the cement paste $\left[1 / \mathrm{m}^{3}\right]$}

Fig. 5 Extent of area affected by honeycomb and bleeding depending on the saturation degree

5. ábra Vérzéssel és fészkességgel érintett felületek nagysága a péptelitettség függvényében

\subsection{Mechanical properties}

The mean value of the measured compressive strength can be seen in Fig. 6 compared to the literature [3]. In general, the compressive strength is higher by using water-cement ratio of 0.50 , however it decreases by a total of $12.9 \%$ with increasing cement paste content of the mixture.

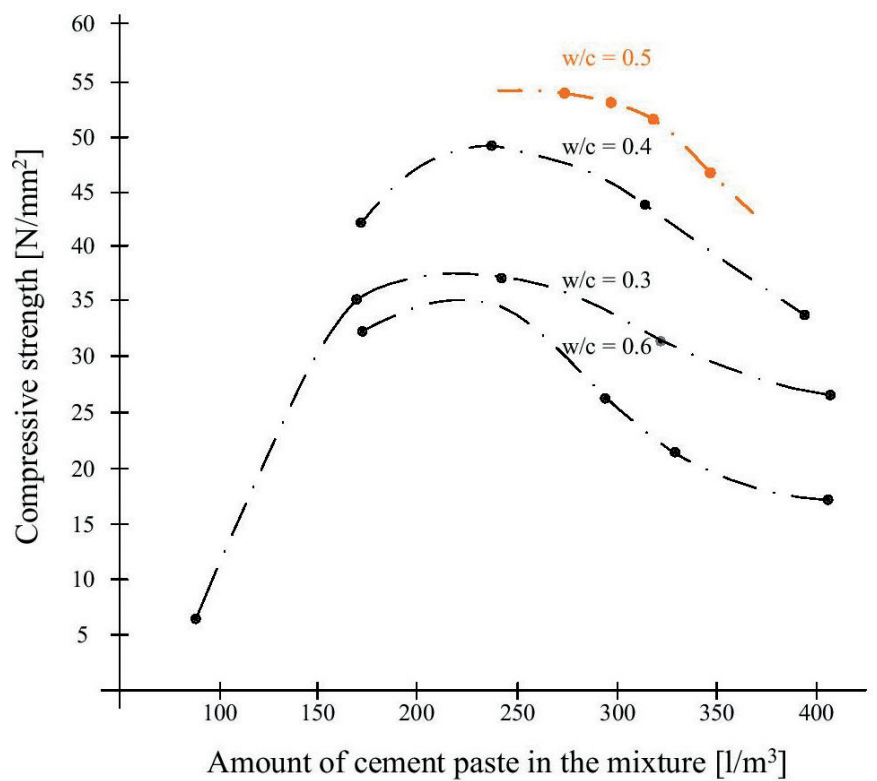

Fig. 6 Compressive strength of concrete depending on cement paste content, (new data coloured) $D=32 \mathrm{~mm}[2]$

6. ábra A beton nyomószilárdsága a péptartalom függvényében (saját adat színesen) $D_{\max }=32 \mathrm{~mm}[2]$

Similar trend can be observed with the flexural strength of concrete, which has a total decrease of $9 \%$ (Fig. 7). The increasing saturation degree of the cement paste has also a negative impact on the water penetration (Fig. 8). 


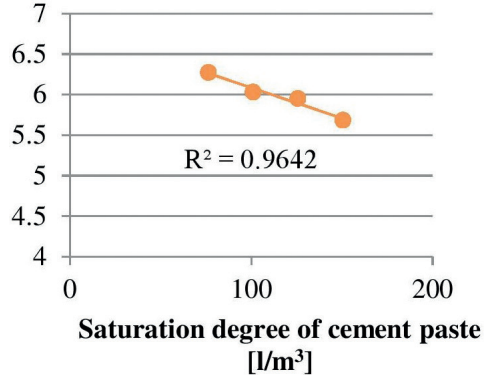

Fig. 7 Flexural strength of concrete depending on the saturation degree of cement paste

7. ábra A beton hajlitó-húzó szilárdsága a péptelítettség függvényében

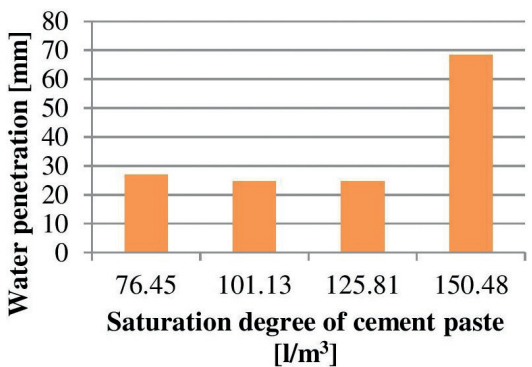

Fig. 8 Results of the water penetration test depending on the saturation degree of cement paste

8. ábra A vízbehatolás mértéke a péptelítettség függvényében

\section{Conclusions}

Based on the laboratory investigations it can be concluded, that both of the saturation degree and of the moulds' dimensions affect the surface quality of the fair-faced concrete elements. With increasing saturation degree of the cement paste the extent of surface void ratio, discoloration, honeycomb and bleeding is decreasing significantly.

\begin{tabular}{|c|c|c|}
\hline Sample & $\begin{array}{l}\text { Class according to the } \\
\text { German guideline }\end{array}$ & $\begin{array}{l}\text { Class according to the } \\
\text { Austrian guideline }\end{array}$ \\
\hline F-1-1 & SB1 & SB1 \\
\hline F-1-2 & SB2 & SB2 \\
\hline F-1-3 & SB4 & SB3 \\
\hline F-1-4 & SB4 & SB3 \\
\hline F-2-1 & SB1 & SB2 \\
\hline F-2-2 & SB3 & SB2 \\
\hline F-2-3 & SB1 & SB2 \\
\hline F-2-4 & SB4 & SB3 \\
\hline F-3-1 & SB2 & SB1 \\
\hline F-3-2 & SB4 & SB2 \\
\hline F-3-3 & SB4 & SB3 \\
\hline F-3-4 & SB4 & SB3 \\
\hline
\end{tabular}

Table 3 Classification of the samples according to the applied guidelines 3. táblázat A felületek osztályba sorolása az alkalmazott irányelvek szerint

The samples made by the fourth, highly oversaturated mixture reached the highest quality class according to the applied regulations (Table 3). In the meantime, the mechanical properties of the concrete decreased, which should be considered especially in the case of load-bearing elements. The increase of dimensions of the mould has a reduced, but also a positive effect on the surface quality in accordance with the evaluated aspects. Based on the results authors recommend to use higher saturation degrees $\left(125-150 \mathrm{l} / \mathrm{m}^{3}\right)$ in the case of slender concrete structures and high or special surface quality with consideration of the changes in mechanical properties.

\section{Acknowledgements}

This article was elaborated in the framework of the project GINOP-2.2.1-15-2016-00030.

\section{References}

[1] Kapu L. (2014) Látszóbeton - Látványbeton, TERC Kft, Budapest, 304 p.

[2] Fenyvesi O., Simon T., Nemes R., Stocker Gy. (2017) Jártunkbankeltünkben, avagy egy Magyarországon eddig nem alkalmazott látszóbeton fajta, Beton, XXV. (II) http://www.betonujsag.hu/lapszamok/ cikk/1940/jartunkban-keltuenkben-avagy-egy-magyarorszagon-eddignem-alkalmazott-latszobeton-fajta

[3] Nehme S.G. (2004) A beton porozitása, PhD értekezés, Budapest University of Technology and Economics

[4] Ujhelyi J.(1980) A beton levegőtartalmának hatása, Magyar Építőipar, 8, pp. $469-481$

[5] MSZ EN 12620 (2006) Aggregates for concrete

[6] Ajtayné K. K., Harrach D., Papp F. (2020) Investigation of the effect of formwork shape on packing density of aggregates, Pollack Periodica: An International Journal for Engineering and Information Sciences, 15 (3) pp. 124-135.

[7] MSZ EN 12350-5 (2009) Testing fresh concrete. Part 5: Flow table test

[8] MSZ EN 24803-6-3:2010 (2010) Épületszerkezetek megjelenési módjának elöŕrásai, Monolit beton- és vasbeton szerkezetek. A helyi alakhüség és a felületi állapot követelményei, Magyar Szabványügyi Testület

[9] ÖNORM B2211 (1998) Beton-, Stahlbeton- und Spannbetonarbeiten Werkvertragsnorm, $9 \mathrm{p}$.

[10] Österreichischen Vereinigung für Beton- und Bautechnik (ÖVBB) Richtlinie (2002) Sichtbeton - Geschalte Betonflächen

[11]Deutscher Beton- und Bautechnik Verein e.V, Bundesverband der Deutschen Zementindustrie (2004) Merkblatt Sichtbeton, $52 \mathrm{p}$.

[12] Stanke G. (2003) Schlussbericht zum Verbundprojekt Baustellenphotogrammetrie - Photogrammetrisches Verfahren als objektorientiertes Ingenieursystem zur Produktionssicherung in der Bauwirtschaft - Teilvorhaben: Sichtbetonalayse, TU Dresden, Rollei Fototechnik, Dywidag, Gesellschaft zur Förderung angewandter Informatik e.V. (GFaI), Berlin, $36 \mathrm{p}$.

[13] Gesellschaft zur Förderung angewandter Informatik e.V. (GFaI), Bundesministerium für Wirtschaft und Technologie (2003) Schlussbericht Sichtbeton II./15940 B - Bildgeschützte Bewertungsverfahren für Sichtbetonoberflächen $42 \mathrm{p}$.

[14] Ajtayné K. K., Horváth A., Papp F. (2020) A new assesment methodology for fair-faced concrete surfaces based on digital image processing, Proceedings of the 13th International PhD Symposium in Civil Engineering, Paris, France, pp. 288-295.

Ref.:

Ajtayné Károlyfi, Kitti - Papp, Ferenc: Laboratory study of the effect of saturation degree on quality of fair-faced concrete surfaces Építőanyag - Journal of Silicate Based and Composite Materials, Vol. 73, No. 3 (2021), 115-118. p. https://doi.org/10.14382/epitoanyag-jsbcm.2021.17 